\title{
Lärdomar från en simulering av humanitär förhandling
}

\author{
Lars Löfquist* \\ Teologiska institutionen, Uppsala universitet
}

\begin{abstract}
Artikeln beskriver en simuleringsövning i förhandling med beväpnade grupper. Övningens planering, genomförande och utvärdering diskuteras. Lärdomar inkluderar att minimera logistik och att låta studenterna driva övningen.
\end{abstract}

Key words: Förhandling, simulering, humanitär, konflikter

Simuleringar eller rollspel är en pedagogisk metod för att återskapa ett verkligt scenario i undervisningslokalen. Simulering är ett exempel på en experimentell undervisningsform och lämpar sig väl för problembaserad inlärning. Dess främsta fördel är att studenter är aktiva deltagare och inte endast passiva observatörer (McKeachie och Svinicki 2006, s. 226). Aktiva undervisningsformer har identifierats av både lärare och studenter som ett av de främsta sätten till att skapa förståelse av teorier och begrepp (Hedin 2006, s.I4f).

Simuleringar är förenade med vissa utmaningar. Eftersom ingen studentgrupp är identisk och förhandlingen är beroende av egenskaper som personlighet och ledarskap är det ej möjligt att förutsäga simuleringens utfall. Dessutom kan simuleringar ses som tidskrävande och kräva omfattande logistik (Lean et al 2006, s. 23If).

Denna artikel syftar till att beskriva en simuleringsövning i förhandling inklusive planering, genomförande och utvärdering som varken kräver mycket planering eller logistik. Speciellt noteras att övningens bidrag främst är relaterat till processen och inte till resultatet.

\section{BAKGRUND}

Simuleringsövningen hölls för studenter inom två masterprogram. Merparten av deltagarna var studenter i termin två på Master programmet i Internationellt humanitärt arbete (Master programme in International Humanitarian Action). Utbildningen är ett två-årigt engelskspråkigt program vid Teologiska institutionen, Uppsala universitet. Programmet drivs i nära samarbete med den humanitära sektorn där huvuddelen av studenterna fortsätter sina karriärer. Studentgruppen var nationellt och åldersmässigt heterogen och merparten av studenterna genomförde övningen under en utbytestermin vid Uppsala universitet.

Det övergripande målet med övningen svarade mot ett centralt lärandemål i kursen; att illustrera hur teori och begrepp inom fredsbyggande och förhandlingsforskning kan vara användbara i en konkret situation. Eftersom många studenter väljer att arbeta inom det humanitära fältet kommer de med stor sannolikhet att möta en förhandlingssituation. Simuleringen avsåg därför främja förmågan att handskas med intressekonflikter där längre förhandlingar och kompromisser ofta är en nödvändig förutsättning för att nå organisatoriska mål.

\footnotetext{
* Författarkontakt: Lars Löfquist, lars.lofquist@teol.uu.se

Artiklar och reflektioner är kollegialt granskade. Övriga bidragstyper granskas av redaktionen. Se www.hogreutbildning.se ISSN 2000-7558

(C)2017 Lars Löfquist. This is an Open Access article distributed under the terms of the Creative Commons Attribution-NonCommercial 4.0 International License (https://creativecommons.org/licenses/by-nc/4.0/), allowing third parties to share their work (copy, distribute, transmit) and to adapt it, under the condition that the authors are given credit, that the work is not used for commercial purposes, and that in the event of reuse or distribution, the terms of this license are made clear.

Citation: Lars Löfquist (2017) «Lärdomar från en simulering av humanitär förhandling», Högre utbildning 7, 76-80. http://dx.doi.org/10.23865/hu.v7.957
} 
Förhandling är en komplex aktivitet som förutsätter kännedom om motparterna, kunskap om egna begräsningar samt förmågan att omvärdera dessa uppfattningar under förhandlingen. Förhandlingar sträcker sig ofta över dagar till veckor. Framgångsrika förhandlingar innefattar tålamod och känslighet, icke verbala förmågor som utvecklas genom erfarenhet. En simulering valdes eftersom lärarstaben hade tidigare erfarenhet av undervisningsformen samt att det var möjligt att utveckla övningen med hjälp av praktiserande förhandlare. Simulering är en återkommande undervisningsform inom förhandlingsträning. Samtidigt måste formen kombineras med lärarnärvaro eftersom simulering i sig ej nödvändigtvis leder till att studenterna når lärandemålen (Druckman och Ebner 2013).

\section{DIDAKTISK TEORI OCH SIMULERING}

Simulering kan förstås på olika sätt. I detta sammanhang ska metoden främst förstås som en typ av interaktivt rollspel. Spelet är utformat för att approximera verkliga situationer. I Rao och Stupans (Rao och Stupans 20I2) terminologi är det en kombination av "agerande" och "nästan verkligt liv" scenario, metoder som används inom högre utbildning i exempelvis juridik och arbetsterapi. Båda metoderna stimulerar kunskap och färdigheter men "nästan verkligt liv" innefattar också en känslomässig dimension. Studenterna har här möjligheten att uppleva en förhandlingssituation men också att utöva sina kunskaper samt syntetisera dessa i ett enhetligt värdesystem, aktiviteter som alla kan återfinnas på högre nivåer av lärande enligt Blooms taxonomi (Rao och Stupans 20I2, s. 43If).

Möjligheten att aktivera den känslomässiga dimensionen sågs som centralt i övningen eftersom förhandling ofta kännetecknas av opposition och manipulation. Studenterna behöver uppleva hur de själva reagerar på denna typ av situation och hur detta är relaterat till förhandlingsteori. Detta är exempel på affektivt lärande, lärande som har: “...effects on emotional and belief systems of participants, such as attitudes towards political systems, appreciation for political actors, motivation and being capable of self- assessment" (Jones och Bursens 2015, 256f) Affektivt lärande fokuserar på att skapa tydligare förståelse för exempelvis beslutsfattares situation men även för hur studenten själv reagerar på situationen, vilket främjar en bättre självbedömning (Jones och Bursens 2015, s. 258f).

\section{PLANERING OCH UPPLÄGG}

Simuleringen föregicks av fyra veckor lektionsundervisning om konflikter och fredsbyggande som genomfördes av lärare med både praktisk och teoretisk kunskap om förhandling. Själva övningen genomfördes dock på grund av tidsbrist av två andra lärare. Övningen utformades för att vara enkel att utföra med begränsad budget, tid och personal.

Upplägget var en veckas arbete med 9 timmar gemensam tid med lärare och studenter, därutöver tillkom olika gruppuppgifter. Kontexten var den Demokratiska republiken Kongo (DRC). Studenterna delades in i grupper inkluderade: Förenta nationernas fredsbevarare (FN), Kongos armé, Huturebeller, Läkare utan gränser, en neutral förhandlingsorganisation samt internationell press. Kontexten valdes eftersom landet präglas av pågående konflikter. Ett fiktivt fall förkastades som alternativ eftersom det skulle kräva omfattande förberedelsearbete. Scenariot var att Läkare utan gränser ska bekämpa ett kolerautbrott i en by men hindras av konflikten mellan armén, FN och rebellerna.

Studenterna fick instruktioner för sin grupp som specificerade vilka intressen som ej var förhandlingsbara samt hur gruppen skulle förhålla sig till de övriga grupperna. De fick också instruktioner för övningen samt en kortare artikel om olika sätt att förhandla. 
Dag 1: Kort introduktion, fördelning av grupptillhörighet. Inläsning på gruppens aktör. Målet med första dagen vad att bekanta sig med aktören samt förbereda ett kort pressmeddelande där aktörens avsikter inför förhandlingen specificeras.

Dag 2: Grupparbete med målet att framställa en förhandlingsstrategi för dag 3. Lämnas in skriftligt via kursportal.

Dag 3: Förhandling 1. Målet var att ge studenterna möjlighet att bekanta sig med varandras aktörer och att försöka identifiera intressen och positioner.

Dag 4: Grupparbete med målet att framställa en förhandlingsstrategi för dag 5. Lämnas in skriftligt via kursportal.

Dag 5: Förhandling 2 samt utvärdering. Sista förhandlingen ska idealt sett leda till en kompromiss varvid Läkare utan gränser för tillåtelse att undsätta byn. Detta skulle speciellt söka främjas av förhandlingsgruppen.

Övningen examinerades på två sätt. Först genom gruppernas strategidokument och sedan genom en individuell analys av övningen. Analysen skulle koncentreras på relationen till tidigare undervisning och litteratur. Lärarnas roll var att cirkulera i grupperna och fungera som bollplank samt att kommunicera nya dynamiska inslag. Ett exempel på ett dynamiskt inslag är om en grupp får information som kan påverka en annan grupp. Idén bakom dessa inslag var att illustrera hur en förhandling kontinuerligt utsätts för omvärldstryck som söker påverka utfallet. Detta förändrar relationen mellan grupperna och kan användas för att nå förhandlingsmål. Dynamiska inslag utmanar också studenternas förmåga att analysera ny information och hur den kan påverka situationen. Samtidigt ökar sådana inslag osäkerheten i övningen vilket kan öka stressen för studenterna (Lean et al 2006, s. 232). Två andra centrala läraruppgifter var att påminna studenterna om deras grupps självförståelse samt att föreslå olika förhandlingsstrategier.

\section{GENOMFÖRANDE}

Deltagarna utgjordes av 24 studenter och två disputerade lärare. Schemat för första dagen följde planeringen. Varje grupp skrev ett kort uttalande om sina respektive positioner. Den neutrala förhandlingsgruppen föreslog ett schema för förhandlingen och grundläggande förhållningsregler om kommunikation, exempelvis respektfullt tilltal. Denna grupp beslutade också att pressen bara fick medverka om alla aktörer vill detta, vilket ej var fallet. Pressgruppen fick därmed lämna undervisningssalen.

Förhandlingen dag tre präglades av återkommande diskussioner om pressens närvarande och hur olika aktörer ställde sig inför detta. Under dagen visade det sig att Läkare utan gränsers och rebellernas intressen sammanföll. Lärarna sökte påverka aktörerna genom dynamiska inslag. Exempelvis fick FN-gruppen möjlighet att hota rebellerna med ett flyganfall och på så sätt pressa fram en kompromiss. En lärare kommunicerade med pressgruppen för att säkerställa deras involvering i processen.

Under sista dagen diskuterades sakfrågan i större detalj. Pressen fick närvara som observatörer men även genomföra intervjuer och ställa frågor vid en presskonferens. Förhandlingens huvudtema vad de villkor som rebellerna respektive armén och FN hade på att tillåta Läkare utan gränsers verksamhet. En kompromiss med en demilitariserad humanitär zon föreslogs av de neutrala men grupperna kunde inte enas innan övningen avslutades. 


\section{UTVÄRDERING}

Simuleringen utvärderades på tre olika sätt. Först genom en gemensam diskussion mellan lärare och studenter i slutet på dag 5 . Den andra utvärderingsformen var att alla studenter fyllde i en utvärderingsenkät. Slutligen skrev varje student en individuell examinatorisk text där målet var att relatera övningen till tidigare lektioner om fredsbyggande och förhandling samt presentera egna reflektioner kring simuleringen.

I de individuella texterna visade studenterna tydligt exempel på affektivt lärande. Följande två citat är illustrerande: "...humanitarian negotiation is a really frustrating process when you do not want to compromise yourself or your institution." "This simulation made me, in a sense, be less naïve in thinking that when the live of people is at risk actors are more prone to agree with each other." Övningen gav både frustration och insikten att människors liv är delar av förhandlingen.

Bland de mer intressanta enkätkommentarerna på övningen återfinns följande. Nästan samtliga studenter, 23 av 24, ansåg att övningen var värdefull. Den illustrerade teorier och exempel som presenterats i tidigare undervisning. Gruppdeltagare identifierade sig starkt med gruppens mål vilket försvårade förhandlingen. Dessutom upplevdes det som svårt att förstå de andra gruppernas perspektiv. Enligt I4 studenter skulle fler dynamiska inslag stärka övningen medan Io var nöjda med nuvarande antal eller ansåg att färre inslag vore bättre. Inslagen som sådana ansågs relevanta men frustrerande eftersom de ändrade villkoren för förhandlingen.

\section{LÄRDOMAR}

En första lärdom är att simuleringar inte behöver vara speciellt komplicerade för att aktivt involvera både studenter och lärare. En enkel struktur ger möjlighet att fokusera på innehållet istället för formella detaljer. Ett intressant fall stimulerar till att lära sig mer om kontextens aktörer vilket i sig ger möjlighet för grupperna att utarbeta sina förhandlingsstrategier. Förberedelsearbetet minskades genom att fallet var direkt tillgängligt och detta förstärkte också relevansen av förhandlingen.

En andra lärdom är att dynamiska inslag uppskattades av studentgruppen men de bör användas sparsamt för att inte störa hela simuleringen. Inslagen kan istället användas för att exempelvis lösa låsta positioner eller för att få gruppen att röra sig från en marginell företeelse till huvudämnet. Lärarna skulle kunna förbereda flera möjliga inslag som kan användas under olika omständigheter. Dynamiska inslag är därmed ett sätt för lärare att få större kontroll över simuleringsprocessen. Detta kan stärka lärare som är ovana med denna undervisningsform.

En tredje lärdom är att om lärarna lämnar utrymme för studenternas idéer samt att strukturen av övningen är avvägd mot lärandemål och examination, så är det inte främst resultatet av simuleringen som är det viktigaste. Även vid ett negativt utfall där de olika parterna inte nådde en lösning fick studenterna chansen att utveckla de kompetenser som övningen ytterst syftade till.

En fjärde lärdom är att den studentnära undervisningsprocessen gav lärare och studenter en tydligare bild av studenternas förmågenivå. Detta är speciellt relevant för affektivt lärande. Denna typ av lärande är en viktig del av professionsnära utbildning men är svår att utveckla utan ett nära samspel mellan studenter och lärare. Simuleringen gjorde det lättare att stimulera affektivt lärande men också att uppfatta lärandet vilket är ett starkt argument för denna undervisningsform. 


\section{FÖRFATTARPRESENTATION}

Lars Löfquist arbetar som programsamordnare för två masterprogram i humanitärt arbete vid teologiska institutionen, Uppsala universitet. Lars disputerade i etik 2008 och är lektor sedan 20I2. Forskningen fokuserar på professionella dygder för humanitära arbetare. Undervisningsinsatsen innefattar övergripande utveckling av programmens pedagogik samt ansvar för kurser inom religion och management.

\section{LITTERATUR}

Druckman, Daniel och Ebner, Noam (2013) "Games, Claims, and New Frames: Rethinking the Use of Simulation in Negotiation Education”. Negotiation Journal, 29(I), 6I-92.

Hedin, Anna (2006) Lärande på Hög nivå: Idéer från studenter, lärare och pedagogisk forskning som stöd för utveckling av universitetsundervisningen. Uppsala universitet Avdelningen för utveckling av pedagogik och interaktivt lärande.

Jones, Rebecca och Bursens, Peter (20I5) "The effects of active learning environments: How simulations trigger affective learning". European Political Science, I4(3), 254-265.

Lean, Jonathan; Moizer, Jonathan; Towler, Michael; Abbey, Caroline (2006) "Simulations and games: Use and barriers in higher education". Active Learning in Higher Education, 7(3), 227-242.

McKeachie, Wilbert och Svinicki, Marilla, red. (2006) McKeachies Teaching Tips: Strategies, Research, and Theory for College and University Teachers. I2 upplagan. Boston: Houghton Mifflin.

Rao, Deepa och Stupans, Ieva (20I2) "Exploring the potential of role play in higher education: development of a typology and teacher guidelines", Innovations in Education and Teaching International, 49(4), 427-436. 